The Impact of Behavioural Factors on

Investment Decision Making and

Performance of CSE Investors in Eastern Province of Sri Lanka
Sri Lanka Journal of

Economic Research

Volume 8(1) December 2020 SLJER 08.01.02: pp. 27-51

Sri Lanka Forum of

University Economists

DOI: http://doi.org/10.4038/sljer.v8i1.123

N Rajeshwaran

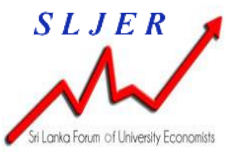

\begin{abstract}
Objectives of the study are twofold; first, to identify behaviour of CSE investors in Eastern province of Sri Lanka; second, to examine how behavioural factors impact on investment performance of CSE investors in the province. The research was conducted from positivism perspective and deductive reasoning was used as research approach. Survey strategy was applied to collect data and time horizon was cross sectional. Proportionate stratified random sampling technique was applied to choose the sample from the districts. Data were collected via questionnaires from 374 investors of CSE in the province. Mean, standard deviation, correlation and multiple regression were applied. Results show that all four behavioural factors and investment performance have fallen to moderate levels. According to Heuristic variables, investors rely on their skill, knowledge and previous experience. The investors mostly avoid loss and regret in investment on stocks as per the Prospect variables. Out of Market variables, the investors carefully consider the price changes of stocks while moderately analyse the companies' customer preference. In line with Herding variable, the investors also follow others' decision to invest. Heuristic variables are positively related with investment performance while other variables namely prospect variables, market variables and Herding variables are negatively related with investment performance. Recommendations are given to current and potential investors as well as executives in the stock market for promoting investment in stock exchange
\end{abstract}

Keywords: CSE Investors, Eastern Province, Investment Performance, Investors' Behaviour

\title{
N Rajeshwaran
}

Department of Commerce, Eastern University, Sri Lanka.

Email: rajesheusl@gmail.com, rajesh@esn.ac.lk Tel: +94779060623

(iD https://orcid.org/0000-0001-8056-9093 


\section{INTRODUCTION}

Traditional financial theories are classical decision theory, rationality, risk aversion, model portfolio theory (MPT), the capital asset pricing model (CAPM), and the efficient market hypothesis (EMH) which is dominant over the several decades (Huang et al., 2016; Fama, 1970). However, Ackert (2014) found that many of the assumptions and findings associated with traditional finance theories are not accurate. Therefore, behavioural finance researchers moved to observe behaviours to develop models that describe how investors actually reach their decisions (Ackert, 2014). "Behavioural finance theories, which are based on psychology attempt to understand how emotions and cognitive errors influence individual investors' behaviors" (Luong and Ha, 2011). Despite there are a lot of studies available pertaining to stock market particularly share price movement, capital structure in Sri Lanka (Menike, 2006; Menike \& Prabath, 2014; Hettiarachchi, \& Rajeshwaran, 2016), investors' behaviour are not clearly studied. A better understanding of behavioural processes and outcomes are important for financial planners. Because, an understanding of how investors generally respond to market movements would help them in devising appropriate asset allocation strategies for clients (Al-Tamimi, 2006).

Potter in 1971 identified six factors that affect individuals' investment behaviour. His results showed dividends, rapid growth and investment for saving purposes, quick profits through trading, professional investment management and long-term growth that affect individual investor's attitudes towards their investment decisions. According to the survey, those factors are most influential to the investors' investment decisions. Similarly, Blume and Friend (1978), using Wharton survey results, provided a comprehensive study on implications of behavioural finance and found that basic measures of risk undertaken by individual investors are price and earning volatility. Further, Abu-Nassar and Rutherford (1996) argued that the annual corporate reports are the most important source of information to make decisions by the different groups of investors. Menike (2006) noted that inflation, interest rates, exchange rates are the most influential factors to the investors to make investment decisions. Sultana and Pardhasaradhi (2012) identified that following factors: individual eccentricity, wealth maximization, risk minimization, brand perception, social responsibility, financial expectation, accounting information, government and media, economic expectation and advocate recommendation, affect the investors' decisions in India. Different scholars indicated different influencing factors on investors' behaviour in different countries.

Sri Lanka is a different country with regard to culture, political and legal settings compared to developed nations as well as some developing countries. Therefore, findings from other countries cannot be applied directly to the Sri Lankan setting. In addition, there is no accurate information regarding investors' behaviour in Colombo Stock Exchange except the study of Kengatharan and Kengatharan (2014). Kengatharan and 
Kengatharan (2014) conducted a study for examining investors' behaviour in Sri Lanka. Their sample size was 128 which is not adequately representing the population of the study and those findings cannot be used to generalize the Sri Lankan setting. Moreover, their study does not reveal investors behaviour of Eastern province in Sri Lanka. Further, the study was conducted before 2014. Therefore, it is necessary to re-conduct the study with adequate sample size representing the population in order to understand the current phenomenon of investors' behavior.

Although 797,192 CSE investors exist in Sri Lanka, only 12,589 investors are existing in Eastern province (Central depository system, 2016). As a preliminary stage the study focuses on behaviour of investors in Eastern province of Sri Lanka. Because a number of CSE investors are less in the province compared with other provinces even though there are a lot of natural resources and investment opportunities available in the province (Ceylontoday, 2016).

After the end of the civil disturbances, many infrastructure development efforts have been undertaken in the province, ranging from from roads to electricity tanks refurbishment, etc. But what is important is to explore the possibility of bringing investment into the region because it has so much potential and resources available in every sector. In order to develop the region, it is necessary to boost the investors in the region. But, unfortunately, not many among the public from the region are involved in investing in CSE. Therefore, understanding CSE investors' behaviour is important to promote the potential investors to invest in the CSE. Consequently, it is expected that such would enhance capital of the public companies, which, in turn, would facilitate bringing new investment opportunities in to the region.

This study was conducted to identify the factors that affect investors' behaviour of Eastern Province towards investment in CSE and to understand how those factors impact on investment performance of investors in the province. It provides new insights about investors' behavior. Findings of the study helps prospective investors to understand the share market operations and how it could be safely and profitably invested than investing in gold or land. As a result, it undoubtedly expands horizons of knowledge regarding the share market, as well as the country's economy. In addition, research findings facilitate security organization to predict the investors' behaviour and provide more reliable consultant information to the investors. Therefore, this research is undertaken.

\section{Problem Statement}

Capital market plays a vital role to fulfill long term financial requirements of the company. In addition, the stock market highly contributes to operations of the companies and national economy (Jaswani, 2008). Nevertheless, individual investment decision making is imperative to determine share market trends as it impacts on the national economy (Kengatharan and Kengatharan, 2014). 
As per the Figure 1, The All Share Price Index (ASPI) and the S\&P SL 20 Index of the CSE declined in 2018. The ASPI decreased by $5.0 \%$ to $6,052.4$ whereas S\&P SL20 index decreased by $14.6 \%$ in 2018 (Central Bank of Sri Lanka, 2018).

\section{Figure 1: ASPI, S\&P SL20 Index and Daily Turnover at the CSE}

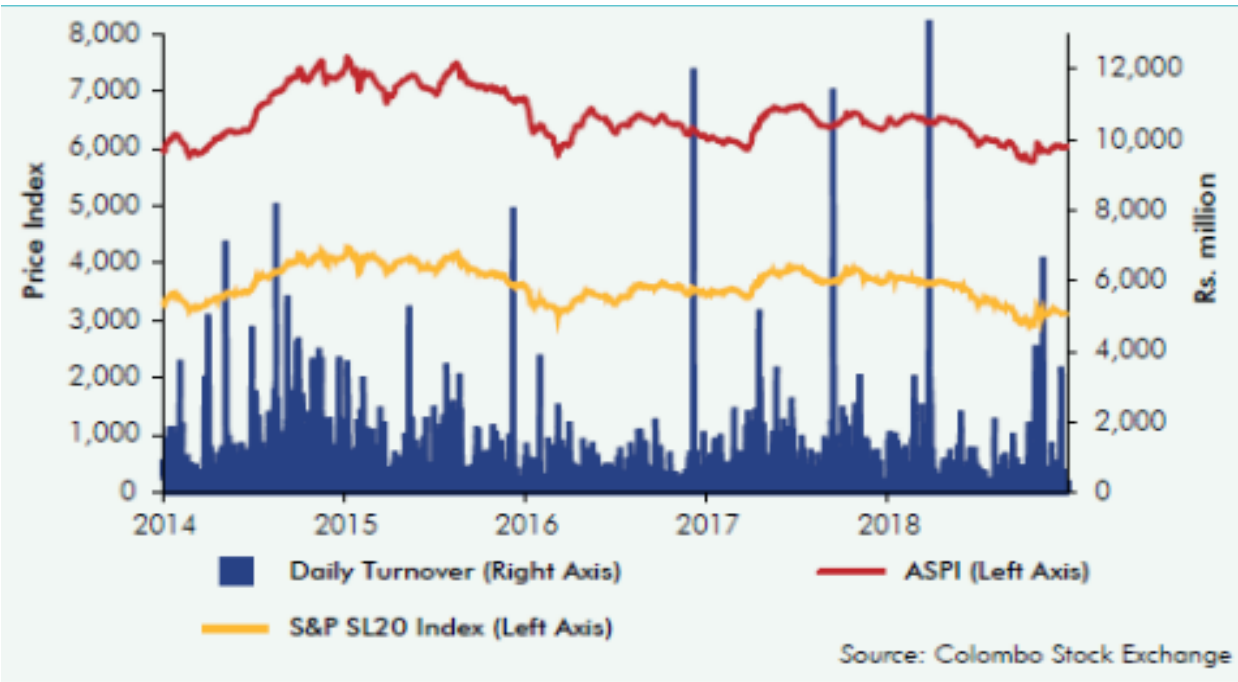

Source: Central Bank of Sri Lanka, 2018, p.283

Figure 2 shows that "In the secondary market, the market recorded a net foreign outflow of Rs. 23.1 billion at end 2018 compared to the net foreign inflow of Rs.17.7 billion at end 2017" (Central Bank of Sri Lanka, 2018).

Stochastic pattern of all share price index and S\&P SL20, declining Market capitalisation of CSE and foreign participation at the CSE revealed that behaviours of investors in CSE are not steady. The Central Bank of Sri Lanka (2018) reported that "Net foreign outflows prevailed in the market during the recent past were mainly driven by the increased pressure on the exchange rate, political uncertainty and the shift in investor sentiments due to global developments". But, the report does not indicate investors' behaviour from the psychological perspective. It is very important because whether Sri Lankan investors follow others' decisions or genuinely apply traditional financial theories to make decisions which are still obscure. Forecasting may be inaccurate using conventional financial theories. Moreover, the level of risk acceptance of the investors depends on their personal characteristics and attitudes to risk (Maditinos, Sevic \& Theriou, 2007). Waweru et al., (2008) also pointed out that behavioural finance is appropriate in this case as it is based on psychology to explain why people buy or sell stocks. Therefore, traditional financial theories may not be suitable in the context of Eastern province due to lack of expertise by the Eastern province investors in traditional financial theories or formulas like CAPM, etc. 


\section{Figure 2: Foreign Participation at the CSE}

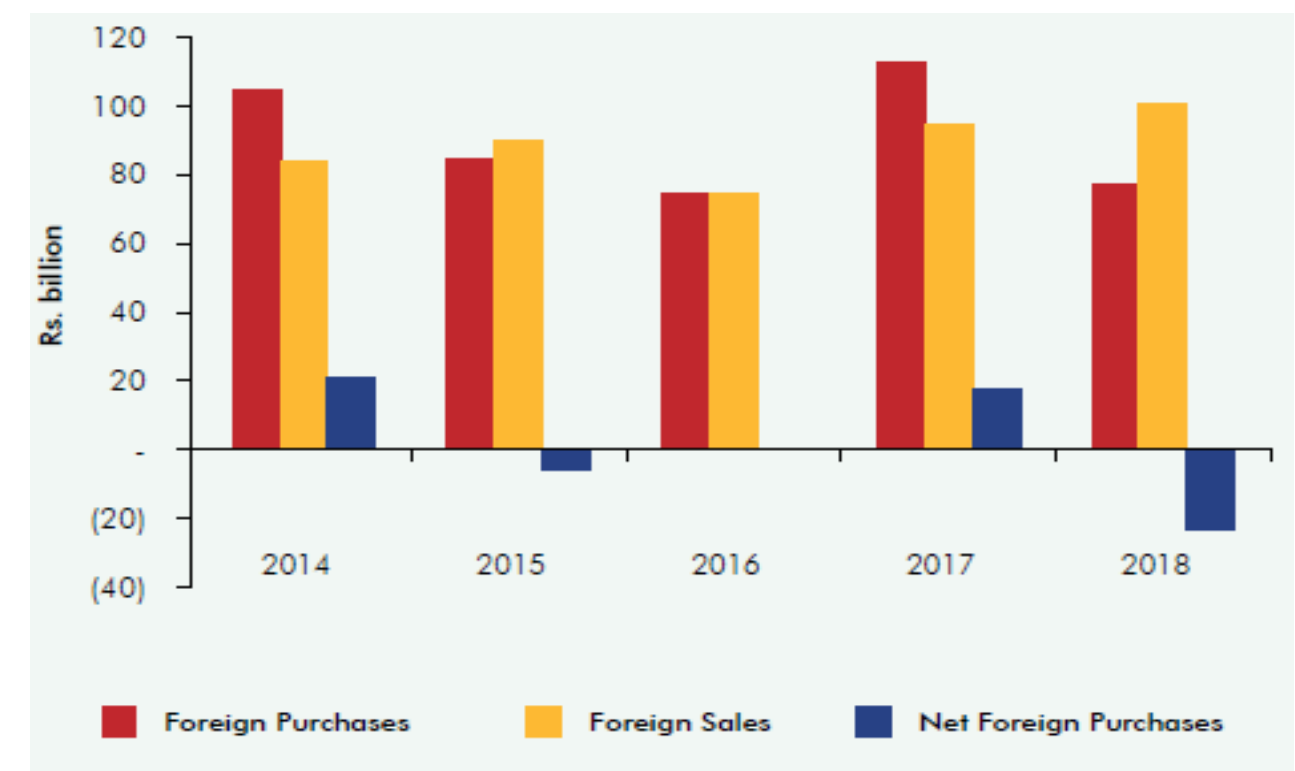

Source: Central Bank of Sri Lanka, 2018, p.284

In spite of the Central Bank of Sri Lanka reports overall performance of CSE, the study specifically focuses Eastern province as a scope of the study in order to understand the investors' behaviour and promote the investors and develop the region. To gain more insights of the investors' decisions, it is essential to examine which behavioural factors influence in decision making process of CSE investors in Eastern Province and how those factors impact on investment performance of investors at Eastern province of Sri Lanka. Therefore, the study tries to find answers to the following research problem. How do behavioural factors impact on investment decision making and performance of CSE investors in Eastern province of Sri Lanka? Objectives of the study are as follows.

i. To identify behaviour of CSE investors in Eastern province of Sri Lanka.

ii. To examine how behavioural factors impact on investment performance of CSE investors in Eastern province of Sri Lanka

\section{THEORETICAL PERSPECTIVES OF BEHAVIOURAL FINANCE}

\section{Heuristic Theory}

According to Ritter (2003), Heuristic refers to rules of thumb which people use to make decisions in complex, uncertain environments. Kahneman and Tversky (1974) identified three dimensions of heuristic, which are representativeness, availability bias and anchoring. Waweru et al., (2008) also added two more dimensions into heuristic theory such as Gambler's fallacy and Overconfidence. 
Representativeness indicates to what extent an event is similar to population (Kahneman and Tversky, 1974). Ritter (2003) posits that representativeness may result in some biases such as people put too much weight on recent experience and ignore the average longterm rate. Gambler's fallacy refers "an individual erroneously believes that the onset of a certain random event is less likely to happen following an event or a series of events (Jeyraj, 2013). In the stock market, Gamblers' fallacy arises when people predict inaccurately the reverse points which are considered as the end of good (or poor) market returns (Waweru et al., 2008). Anchoring is a phenomenon used in the situation when people use some initial values to make estimation, which are biased toward the initial ones as different starting points yield different estimates (Kahneman \& Tversky, 1974). In the financial market, anchoring arises when a value scale is fixed by recent observations. Investors always refer to the initial purchase price when selling or analyzing. Overconfidence happens as people overestimate the reliability of their skills, knowledge and accuracy of their information, or over optimistic about the future and the ability to control the situations (Camerer \& Lovallo, 1999; Hirshleifer, 2001; Glaser \& Weber, 2007). Availability denotes investors make use of easily available information excessively (Waweru et al., 2008).

\section{Prospect Theory}

Prospect theory assumes that losses and gains are valued differently, thus individuals make decisions based on perceived gains instead of perceived losses. Losses cause a greater emotional impact than does an equivalent of gain (Kahneman \& Tversky (1979). Prospect theory explains some states of mind affecting an individual's decision-making processes including Regret aversion, Loss aversion and mental accounting (Waweru et al., 2003).

Regret is an emotion that occurs after people make mistakes. Investors avoid regret by refusing to sell decreasing shares and willing to sell increasing ones (Fogel \& Berry, 2006; Lehenkari \& Perttunen, 2004). Regret aversion is the tendency to avoid actions that could create discomfort over prior decisions, even though those actions may be in the individual's best interest. Loss aversion refers to the difference level of mental penalty people have from a similar size loss or gain (Barberis \& Huang, 2001). There is evidence showing that people are more distressed at the prospect of losses than they are pleased by equivalent gains (Barberis \& Thaler, 2003). Mental accounting is a term referring to the process by which people think about and evaluate their financial transactions (Barberis $\&$ Huang, 2001). Mental accounting allows investors to organize their portfolio into separate accounts (Barberis \& Thaler, 2003; Ritter, 2003).

\section{Market Factors}

DeBondt and Thaler (1995) state that financial markets can be affected by investors' behaviors in the way of behavioural finance. Waweru et al., (2008) identifies the factors 
of the market that have an impact on investors' decision making: Price changes, market information, past trends of stocks, customer preference, over-reaction to price changes, and fundamentals of underlying stocks.Normally, changes in market information, fundamentals of the underlying stock and stock price can cause over/under-reaction to the price change. Researchers believe that over-reaction (DeBondt \& Thaler, 1985) or underreaction (Lai, 2001) to news may result in different trading strategies by investors and hence influence their investment decisions. Moreover, Barber and Odean (2000) emphasize that investors are impacted by events in the stock market which grab their attention, even when they do not know if these events can result in good future investment performance. Odean (1998) explores that many investors trade too much due to their overconfidence. These investors totally rely on the information quality of the market or stocks that they have when making decisions of investment.

Waweru et al. (2008) indicate that price change of stocks has an impact on their investment behaviour at some level. Odean (1999) states that investors prefer to buy and sell stocks that experience higher price changes during the past two years. Many investors tend to focus on popular stocks or hot stocks in the market (Waweruet al., 2008). Odean (1999) proposes that investors usually choose the stocks that attract their attention. Besides, the stock selection also depends on the investors' preferences. Momentum investors may prefer stocks that have good recent performance while rational investors tend to sell the past losers and this may help them to postpone taxes. In contrast, behavioural investors prefer selling their past winners to postpone the regret related to a loss that they can meet for their stock trading decisions (Waweru et al., 2008). Besides, past trends of stocks are also explored to impact the decision making behaviour of the investors at a certain level by Waweru et al. (2008).

\section{Herding Effect}

Herd Behaviour or herd mentality is the behaviour of an investor who imitates the action of other investors or follows the movement of the market instead of relying on their own strategic information (Biekhchandani \& Sharma, 2001). Barber et al. (2009) reported that investors trend to behave wrongly on or around the same time. These investors do not necessarily remove the others' actions. In that case, individual investors cannot be considered as noise traders, they are regarded as a big organization which has a large impact on the stock market, causing stock prices do not reflect actual and rational values.

Herd mentality is expressed in the perspective in which investors follow the behaviors of their peers and do not act in contrast to them whatever they have any information. Herd behaviour may be the most generally recognized observation on financial markets in a psychological context. Even completely rational people can participate in herd behaviour when they take into account the judgments of others, and even if they know that everyone else is behaving in a herd like manner. An important variable to herding is the word of 
mouth. People generally trust friends, relatives and colleagues more than they do the media. It's therefore likely that news about a buying opportunity will rapidly spread. Shiller \& Pound (1986) show that even if people read a lot, their attention and actions appear to be more stimulated by interpersonal communications.

\section{Investment Performance}

Previous researches (Lin and Swanson, 2003; Kim and Nofsinger, 2003) objectively measured Investment performance based on secondary data. However, rate of return on shares is used to measure Investment performance (Oberlechner and Osler, 2004). But, return rate is evaluated to measure investment performance via questionnaire with the combination of objective and subjective perspectives in this research. Objective viewpoint is focused by comparing real return rate with average market return while subjective viewpoint is focused by comparing real return rate with the investors' expected return rate. As per Luong and Ha (2011) criterion to measure investment performance, investors' satisfaction on investment decisions is also used in this study to measure investment performance.

\section{RESEARCH METHODOLOGY}

The research was conducted with the ontological assumption of objectivism as the reality was existing external to the researchers. Epistemological perspective of the study was positivism. Quantitative method was applied to understand the phenomenon.

\section{Data Source, Population and Sample}

The target population of this study was all the investors drawn from CSE representing three districts. According to the data collected from Central Depository System (pvt) ltd., there were 5,688; 3,766 and 3,135 investors in CSE from the three districts Ampara, Batticaloa and Trincomalee, respectively. Sample size was determined based on the table of sample size for a given population size (Krejcie and Morgan, 1970, cited in Sekaran, 2007 , p.294). Further, sample size was confirmed by a sample calculator on the web using 95\% confidence level and 5\% confidence interval (The survey system, 2018).

According to proportionate stratified random sampling technique, 169, 112 and 93 were taken as a sample in each district Ampara, Batticaloa and Trincomalee, respectively. Therefore, the total sample size was 374 in three districts. The data were collected through a structured questionnaire. The respondents were selected based on the list taken from stock brokers of CSE.

\section{Model Specification}

Heuristic theory and Prospect theory are employed to examine the study. In addition to the above theories Market factors and Herding effect also considered to conduct the study. 
Heuristic Variables, Prospect Variables, Market Variables and Herding Variables are identified as independent variables and Investment Performance of individual investors at CSE is considered as dependent variable. Conceptual model of the study is depicted below in Figure 3.

Figure 3: Conceptual framework of the study

\begin{tabular}{|l|l|}
\hline \multicolumn{1}{|c|}{ Behavioral Factors } & \\
Heuristic Variables & $\longrightarrow$ \\
Prospect Variables \\
Market Variables \\
Herding Variables
\end{tabular}$\quad$\begin{tabular}{c} 
Investment Performance of \\
CSE investors in Eastern \\
Province of Sri Lanka \\
\hline
\end{tabular}

Source: Luong and Ha, 2011; Kengatharan and Kengatharan, 2014

By considering above arguments presented in previous research findings (Luong and Ha, 2011; Kengatharan and Kengatharan, 2014), the alternative hypothesis of the study is formulated as follows.

H: There is a positive impact of Behavioural factors (Heuristic/ Prospect/ Market/ Herding) on the Investment Performance of CSE investors in Eastern province of Sri Lanka.

\section{Analytical Tools and Techniques}

The collected data are analyzed through SPSS software packages. Descriptive Statistics (mean, standard deviation) were used to describe respondents' personal information. Descriptive statistics were also used to describe the influence level of behavioural variables on the investment performance of stockholders according to the following decision rule.

Table 1: Decision Attribute

\begin{tabular}{ll}
\hline Range & Decision attributes \\
\hline $1.0<\mathrm{Xm} \leq 2.5$ & Low level \\
\hline $2.5<\mathrm{Xm} \leq 3.5$ & Moderate level \\
\hline $3.5<\mathrm{Xm} \leq 5.0$ & High level \\
\hline
\end{tabular}

$X m=$ Mean of variables 
Regression model is as follows.

$\mathrm{IP}=\beta_{0}+\beta_{1}(\mathrm{HV})+\beta_{2}(\mathrm{PV})+\beta_{3}(\mathrm{MV})+\beta_{4}(\mathrm{HDV})+e$

Where:

$\beta_{0} \quad$ The Intercept $\quad \beta_{1} \quad$ Slope of Heuristic Variables

$\beta_{2} \quad$ Slope of Prospect Variables $\quad \beta 3 \quad$ Slope of Market Variables

$\beta_{4} \quad$ Slope of Herding Variables HV Heuristic Variables

PV Prospect Variables MV Market Variables

HDV Herding Variables IP Investment Performance

e $\quad$ Error term

\section{FINDINGS AND DISCUSSION}

Nunnally (1978) suggests that Cronbach's alpha should be at least 0.7 to make sure that the measurements are reliable. Cronbach's alpha of all variables is 0.846 which shows that reliability of the data is high as it is higher than 0.7 .

\section{Analysis of Number of Respondents}

After getting the willingness to respond to the questionnaire by phone, questionnaires were emailed to respective persons. As e-mail response rate was poor, the researcher personally visited the respondent place for the purpose of data collection. Six incomplete questionnaires were judged unusable and excluded from the data analysis. The respondents refused to complete the questionnaires, claiming that it is sensitive and confidential information. After excluding the incomplete responses, the research ended with 312 valid and usable questionnaires, representing $83 \%$ response rate. This response rate is considered as a high response rate in this kind of empirical survey. Table 2 provides the number of questionnaires collected from the sample distribution by district.

Table 2: Respondents by Districts

\begin{tabular}{lccc}
\hline Districts & Issued & \multicolumn{2}{c}{ Collected } \\
\cline { 3 - 4 } & & Number & Percent \\
\hline Ampara & 169 & 141 & 45 \\
\hline Batticaloa & 112 & 103 & 33 \\
\hline Trincomalee & 93 & 68 & 22 \\
\hline Total & $\mathbf{3 7 4}$ & $\mathbf{3 1 2}$ & $\mathbf{1 0 0}$ \\
\hline
\end{tabular}

Source: Survey data 


\section{Profiles of Respondents}

Table 3: Profiles of Respondents

\begin{tabular}{|c|c|c|c|}
\hline Profile & Category & Number & Percent \\
\hline \multirow[t]{2}{*}{ Gender } & Male & 244 & 78 \\
\hline & Female & 68 & 22 \\
\hline \multirow[t]{5}{*}{ Age } & $18-25$ & 18 & 6 \\
\hline & $26-35$ & 97 & 31 \\
\hline & $36-45$ & 119 & 38 \\
\hline & $46-55$ & 54 & 17 \\
\hline & Over 55 & 24 & 8 \\
\hline \multirow[t]{2}{*}{ Marital Status } & Single & 66 & 21.2 \\
\hline & Married & 246 & 78.8 \\
\hline \multirow[t]{5}{*}{ Education } & $\mathrm{A} / \mathrm{L}$ & 94 & 30.1 \\
\hline & Graduate & 147 & 47.1 \\
\hline & Postgraduate/ Masters & 50 & 16 \\
\hline & $\mathrm{PhD}$ & 9 & 2.9 \\
\hline & Other & 12 & 3.8 \\
\hline \multirow[t]{3}{*}{ Years of Working } & Below 5 & 72 & 23.1 \\
\hline & 10-May & 96 & 30.8 \\
\hline & Over 10 & 144 & 46.2 \\
\hline \multirow{5}{*}{$\begin{array}{l}\text { Average monthly } \\
\text { income (LKR) }\end{array}$} & Below 25000 & 24 & 7.7 \\
\hline & $25000-49999$ & 144 & 46.2 \\
\hline & $50000-74999$ & 44 & 14.1 \\
\hline & 75000 - 99999 & 51 & 16.3 \\
\hline & 100000 and Above & 49 & 15.7 \\
\hline \multirow{6}{*}{$\begin{array}{l}\text { Number of years } \\
\text { attended the stock } \\
\text { market }\end{array}$} & $1-2$ years & 114 & 36.5 \\
\hline & $3-4$ years & 82 & 26.3 \\
\hline & $5-6$ years & 71 & 22.8 \\
\hline & 7 - 8 years & 12 & 3.8 \\
\hline & $9-10$ years & 6 & 1.9 \\
\hline & Above 10 years & 27 & 8.7 \\
\hline \multirow[t]{2}{*}{ Stock Market Related Course } & Yes & 80 & 25.6 \\
\hline & No & 232 & 74.4 \\
\hline The total investment (LKR) & Below 50000 & 64 & 20.5 \\
\hline \multirow[t]{5}{*}{ at Colombo Stock Exchange } & $50000-99999$ & 66 & 21.2 \\
\hline & $100000-149999$ & 33 & 10.6 \\
\hline & $150000-199999$ & 32 & 10.3 \\
\hline & $200000-249999$ & 30 & 9.6 \\
\hline & 250000 and Above & 87 & 27.9 \\
\hline
\end{tabular}

Source: Survey data 
Table 3 provides an overview of respondents' profiles such as Gender, Age, Marital Status, Education, and Number of years attended the stock market, etc. Around $78 \%$ of males participated in the survey. Out of the total respondents, about $38 \%$ of respondents are fallen in the category of age 36-45. Most of respondents (66\%) are graduate and postgraduate qualifications while the rest of them do not have academic qualifications. Most of them are invested in the stock market without following stock market related courses. It is also noted that approximately $28 \%$ of respondents invested Rs. 250,000 and above in the stock market while $20 \%$ of participants invested Rs. 50,000 and below in the market.

\section{Descriptive Statistics}

Descriptive Statistic for Heuristic variables

Table 4: Descriptive Statistics for Heuristic Variables

\begin{tabular}{|c|c|c|c|}
\hline Dimension & Indicators & Mean & $\begin{array}{c}\text { Std. } \\
\text { Deviation }\end{array}$ \\
\hline \multirow[t]{2}{*}{ Representativeness } & $\begin{array}{l}\text { I always buy 'hot' stocks and avoid stocks } \\
\text { that have performed poorly in the recent past. }\end{array}$ & 3.46 & 0.98 \\
\hline & $\begin{array}{l}\text { I frequently use trend analysis of some } \\
\text { representative stocks to make investment } \\
\text { decisions for all stocks that I invest. }\end{array}$ & 3.39 & 1.01 \\
\hline Overconfidence & $\begin{array}{l}\text { I believe that my skills and knowledge of the } \\
\text { stock market can help me to extremely } \\
\text { outperform the market. }\end{array}$ & 3.49 & 0.96 \\
\hline \multirow[t]{2}{*}{ Anchoring } & $\begin{array}{l}\text { I always rely on my previous experiences in } \\
\text { the market for my next investment. }\end{array}$ & 3.78 & 0.84 \\
\hline & $\begin{array}{l}\text { I usually forecast the changes in stock prices } \\
\text { in the future based on the recent stock prices. }\end{array}$ & 3.09 & 1.06 \\
\hline Gambler's Fallacy & $\begin{array}{l}\text { I am normally able to anticipate the end of } \\
\text { good or poor market returns at the Colombo } \\
\text { Stock Exchange. }\end{array}$ & 3.14 & 1.00 \\
\hline Availability & $\begin{array}{l}\text { I typically prefer to buy local stocks than } \\
\text { international stocks because the information } \\
\text { of local stocks is more available. }\end{array}$ & 3.57 & 1.08 \\
\hline \multicolumn{2}{|c|}{ Overall Heuristic Variable } & 3.42 & 0.61 \\
\hline
\end{tabular}

Source: Survey Data 
According to the decision rule, one of the indicators of Anchoring has the highest mean (Table 4, above). Thus, investors mostly rely on their previous experiences in the market for their next investment with mean 3.78 and standard deviation 0.84. In terms of Availability, it is high level. Similarly, overconfidence is approached at a high level (mean $=3.49$ ). Respondents believe that their skills and knowledge of the stock market can help them to extremely outperform the market whereas they typically prefer to buy local stocks than international stocks. Representativeness has the moderate level on the investment performance. Although they always buy 'hot' stocks and avoid stocks that have performed poorly in the recent past, they are poor in accurately forecasting the changes in stock prices in the future based on the recent stock prices. Gambler's fallacy is the lowest mean value (3.14), which is considered as a moderate level as they are not smart in anticipating market return.

\section{Descriptive Statistics for Prospect Variables}

The Prospect variables and their respective descriptive statistics are provided in a summarized form in the Table 5.

Table 5: Descriptive Statistics for Prospect Variables

\begin{tabular}{|c|c|c|c|}
\hline Dimension & Indicators & Mean & $\begin{array}{l}\text { Std. } \\
\text { Deviation }\end{array}$ \\
\hline \multirow[t]{2}{*}{$\begin{array}{l}\text { Loss } \\
\text { aversion }\end{array}$} & $\begin{array}{l}\text { After a prior gain, I am more risk seeking than } \\
\text { usual. }\end{array}$ & 3.32 & 1.05 \\
\hline & After a prior loss, I become more risk averse. & 3.47 & 0.87 \\
\hline \multirow[t]{2}{*}{$\begin{array}{l}\text { Regret } \\
\text { Aversion }\end{array}$} & $\begin{array}{l}\text { I generally avoid selling shares that have } \\
\text { decreased in value and readily sell shares that have } \\
\text { increased in value. }\end{array}$ & 3.50 & 0.73 \\
\hline & $\begin{array}{l}\text { I feel more sorrow about holding losing stocks too } \\
\text { long than about selling winning stocks too soon. }\end{array}$ & 3.48 & 1.11 \\
\hline \multirow[t]{2}{*}{$\begin{array}{l}\text { Mental } \\
\text { Accounting }\end{array}$} & $\begin{array}{l}\text { I usually tend to treat each element of my } \\
\text { investment portfolio separately. }\end{array}$ & 3.64 & 0.74 \\
\hline & $\begin{array}{l}\text { I commonly ignore the connection between } \\
\text { different investment possibilities. }\end{array}$ & 2.97 & 1.10 \\
\hline \multicolumn{2}{|c|}{ Overall Prospect Variables } & 3.40 & 0.50 \\
\hline
\end{tabular}

Source: Survey Data 
Mental accounting is higher level and highest mean value (3.64) in Prospect variables. Majority of investors tend to treat each element of their investment portfolio separately. Moreover, most of them disagreed that they commonly ignore the connection between different investment possibilities. That is, they agreed to observe the connection among the investment opportunities within a sector. In addition, the study reveals that generally avoid selling shares that have decreased in value and readily sell shares that have increased in value. It indicates that most respondents are Regret aversion on the decision making of the investors at the CSE due to mean falls about higher level. Although investors have prior gain, they do not risk seeking more than usual. Further, after prior loss, they are more risk averse. This phenomenon reveals that the investors are focusing on loss aversion. However, mean value (3.40) of overall Prospect Variables falls in moderate level.

\section{Descriptive Statistics for Market Variables}

Descriptive statistics for Market Variables are provided in the Table 6.

Table 6: Descriptive Statistics for Market Variables

\begin{tabular}{llcc}
\hline Dimension & Indicators & Mean & $\begin{array}{c}\text { Std. } \\
\text { Deviation }\end{array}$ \\
\hline Price changes & $\begin{array}{l}\text { I consider carefully the price changes of } \\
\text { stocks that I intend to invest. }\end{array}$ & 3.73 & 0.81 \\
\hline Market information & $\begin{array}{l}\text { Market information is very important for } \\
\text { my stock investment. }\end{array}$ & 3.70 & 1.19 \\
\hline $\begin{array}{l}\text { Over reaction } \\
\text { price changes }\end{array}$ & $\begin{array}{l}\text { I have the over-reaction to price changes } \\
\text { of stocks. }\end{array}$ & 2.94 & 0.99 \\
\hline $\begin{array}{l}\text { Past trends of stocks } \\
\text { I generally consider past trends of stocks } \\
\text { for my investment. }\end{array}$ & $\begin{array}{l}\text { I analyze the companies' customer } \\
\text { preference before I invest in the stocks. }\end{array}$ & \multirow{2}{*}{3.21} & 1.05 \\
\hline $\begin{array}{l}\text { Customer } \\
\text { preference }\end{array}$ & $\begin{array}{l}\text { I mostly study about the market } \\
\text { fundamentals of underlying stocks before } \\
\text { making investment decisions. }\end{array}$ & 3.35 & 1.14 \\
\hline $\begin{array}{l}\text { Fundamentals } \\
\text { Underlying stocks }\end{array}$ & $\mathbf{3 . 3 8}$ & $\mathbf{0 . 7 1}$ \\
\hline Overall Market Variables & & \\
\hline
\end{tabular}

Source: Survey Data

According to the mean value (Table 6), Price changes of shares as well as Market information are highly considered by the investors for making investment decisions. Other market factors are moderate level. In spite of highly focusing price changes of 
shares (mean 3.73), the respondents are not much overreacting price changes (mean 2.94). Based on findings of Customer preference, they moderately analyze the companies' customer preference before they invest in the stocks as mean 3.21 and standard deviation 1.11. This standard deviation shows while few investors highly focus on companies' customer preference others are not care about the customers' preference.

\section{Descriptive Statistics for Herding Variables}

Level of Herding variables on the investors' decisions at the CSE is moderate (mean=2.98) and standard deviation of the variable is 0.83 . Mean value of other investors' decisions of buying and selling stock is the highest among herding variables while speed of herding is lowest. As per the Table 7, Decisions of other investors are substantially influenced on investors in Eastern province for making decisions pertaining to buying, selling and choosing stock types.

Table 7: Descriptive Statistics for Herding Variables

\begin{tabular}{|c|c|c|c|}
\hline Dimension & Indicators & Mean & $\begin{array}{c}\text { Std. } \\
\text { Deviation }\end{array}$ \\
\hline $\begin{array}{l}\text { Decisions of other } \\
\text { investors: Buying } \\
\text { and Selling }\end{array}$ & $\begin{array}{l}\text { Other investors' decisions of buying } \\
\text { and selling stocks have always impact } \\
\text { on my investment decisions. }\end{array}$ & 3.16 & 0.96 \\
\hline $\begin{array}{l}\text { Decisions of other } \\
\text { investors: Choice of } \\
\text { stock }\end{array}$ & $\begin{array}{l}\text { Other investors' decisions of choosing } \\
\text { stock types have always impact on my } \\
\text { investment decisions. }\end{array}$ & 3.07 & 1.10 \\
\hline $\begin{array}{l}\text { Decisions of other } \\
\text { investors: Volume of } \\
\text { stock }\end{array}$ & $\begin{array}{l}\text { Other investors' decisions of the stock } \\
\text { volume have an impact on my } \\
\text { investment decisions. }\end{array}$ & 2.88 & 0.97 \\
\hline $\begin{array}{l}\text { Decisions of other } \\
\text { investors: Speed of } \\
\text { herding }\end{array}$ & $\begin{array}{l}\text { I usually react quickly to the changes } \\
\text { of other investors' decisions and follow } \\
\text { their reactions to the stock market. }\end{array}$ & 2.82 & 0.93 \\
\hline \multicolumn{2}{|c|}{ Overall Herding Variables } & 2.98 & 0.83 \\
\hline
\end{tabular}

Source: Survey Data

\section{Descriptive Statistics for Investment Performance}

Overall mean value of Investment Performance is 3.18, which indicates that investment performance is moderate level in Eastern province. Nevertheless, there are variations among the investors about the level of investment performance as standard deviation is 
1.02. It denotes that while some of investors are satisfied about their return for the investment whereas the rest of them are suffering due to loss in their investment.

Table 8: Descriptive Statistics for Investment Performance

\begin{tabular}{lcc}
\hline Indicators & Mean & $\begin{array}{c}\text { Std. } \\
\text { Deviation }\end{array}$ \\
\hline $\begin{array}{l}\text { The return rate of my recent stock investment regularly meets } \\
\text { my expectation. }\end{array}$ & 3.22 & 1.12 \\
\hline $\begin{array}{l}\text { My rate of return is always equal to or higher than the average } \\
\text { return rate of the market. }\end{array}$ & 3.17 & 1.08 \\
\hline $\begin{array}{l}\text { I highly satisfied with my investment decisions in the last year } \\
\text { (including selling, buying, choosing stocks, and deciding the } \\
\text { stock volumes). }\end{array}$ & & 1.13 \\
\hline Overall Investment Performance & $\mathbf{3 . 1 8}$ & $\mathbf{1 . 0 2}$ \\
\hline
\end{tabular}

Source: Survey data

\section{Correlation Analysis}

Relationship between heuristic variables and investment performance of individual investors is moderately positive at $1 \%$ significant level in Table 9.

Table 9: Correlation Analysis

\begin{tabular}{|c|c|c|c|c|c|}
\hline & & Prospect & Market & Herding & $\begin{array}{l}\text { Investment } \\
\text { Performance }\end{array}$ \\
\hline \multirow[t]{2}{*}{ Heuristic } & Pearson Correlation & $0.353 * *$ & $0.596^{* *}$ & $0.430 * *$ & $0.310 * * *$ \\
\hline & Sig. (2-tailed) & 0.000 & 0.000 & 0.000 & 0.000 \\
\hline \multirow[t]{2}{*}{ Prospect } & Pearson Correlation & & $0.451 * *$ & $0.225 * *$ & $-0.123 * *$ \\
\hline & Sig. (2-tailed) & & 0.000 & 0.000 & 0.029 \\
\hline \multirow[t]{2}{*}{ Market } & Pearson Correlation & & & $0.494 * *$ & -0.070 \\
\hline & Sig. (2-tailed) & & & 0.000 & 0.221 \\
\hline \multirow[t]{3}{*}{ Herding } & Pearson Correlation & & & & -0.029 \\
\hline & Sig. (2-tailed) & & & & 0.612 \\
\hline & $\mathrm{N}$ & 312 & 312 & 312 & 312 \\
\hline
\end{tabular}

Significance levels are indicated by *,**,*** for $10 \%, 5 \%$ and $1 \%$, respectively.

Source: Survey Data 
This shows that their previous experiences gained in the market help them to earn profit from their investment. Therefore, investors come forward and involve in CSE in order to become an expert in this field. However, prospect variables are negatively correlated with investment performance of individual investors at 5\% significance level. When the investors increase the level of Loss Aversion as well as Regret Aversion, return on investment decreases. Though market and herding variables are negatively associated with investment performance, the results are not significant.

\section{Regression Analysis}

Table 10 reports OLS estimate of Investors' Behaviour on Investment Performance.

Table 10: OLS estimate of Investors' Behaviour on Investment Performance $(\mathrm{N}=312)$

\begin{tabular}{|c|c|c|c|c|c|}
\hline \multirow{3}{*}{$\begin{array}{l}\text { Independent } \\
\text { variables }\end{array}$} & \multicolumn{5}{|c|}{ Dependent variable: Investment Performance } \\
\hline & \multicolumn{4}{|c|}{ Separate Regression } & Multiple Regression \\
\hline & Model 1 & Model 2 & Model 3 & Model 4 & Model 5 \\
\hline \multirow{3}{*}{$\beta_{0}$} & $1.411 * * *$ & $4.027 * * *$ & $3.513 * * *$ & $3.282 * * *$ & $2.819 * * *$ \\
\hline & $(0.000)$ & $(0.000)$ & $(0.000)$ & $(0.000)$ & $(0.000)$ \\
\hline & {$[0.312]$} & {$[0.392]$} & {$[0.280]$} & {$[0.216]$} & {$[0.393]$} \\
\hline \multirow[t]{3}{*}{ Heuristic } & $0.517 * * *$ & & & & $0.981 * * *$ \\
\hline & $(0.000)$ & & & & $(0.000)$ \\
\hline & {$[0.090]$} & & & & {$[0.107]$} \\
\hline \multirow[t]{3}{*}{ Prospect } & & $-0.250 * *$ & & & $-0.360 * * *$ \\
\hline & & $(0.029)$ & & & $(0.002)$ \\
\hline & & {$[0.114]$} & & & {$[0.115]$} \\
\hline \multirow[t]{3}{*}{ Market } & & & -0.099 & & $-0.417 * * *$ \\
\hline & & & $(0.221)$ & & $(0.000)$ \\
\hline & & & {$[0.081]$} & & {$[0.100]$} \\
\hline \multirow[t]{3}{*}{ Herding } & & & & -0.035 & $-0.121 *$ \\
\hline & & & & $(0.612)$ & $(0.096)$ \\
\hline & & & & {$[0.070]$} & {$[0.072]$} \\
\hline \multirow[t]{2}{*}{$\mathrm{F}$} & $33.025 * * *$ & $4.978 * *$ & 1.505 & 0.257 & $22.629 * * *$ \\
\hline & $(0.000)$ & $(0.029)$ & $(0.221)$ & $(0.612)$ & $(0.000)$ \\
\hline $\mathrm{r}$ & 0.310 & 0.123 & & 0.029 & 0.477 \\
\hline $\mathrm{R}^{2}$ & 0.096 & 0.015 & & 0.001 & 0.228 \\
\hline Adjusted $\mathrm{R}^{2}$ & 0.093 & 0.012 & & -0.002 & 0.218 \\
\hline
\end{tabular}

$P$-values are shown in parentheses and standard errors are reported in square brackets. Significance levels are indicated by *,**,*** for 10\%, 5\% and 1\%, respectively.

Source: Survey data 
There are five models shown in the table. Four simple regressions for each independent variable from model 1 to 4 and model 5 is multiple regression. Among the independent variables, only heuristic variables are positively related with the investment performance. At the same time, other variables are negatively related with investment performance as per the simple regression. However, only the prospect variable is significant among three independent variables.

According to multiple regression (model 5), F statistic shows that model is fitness and determination of coefficient $\left(\mathrm{R}^{2}\right)$ is 0.228 which indicates that around $23 \%$ of variation of the dependent variable (investment performance of individual investors) can be explained by the encompassing all independent variables (heuristic variables, prospect variables, market variables and herding variables). Adjusted $\mathrm{R}$ square $21.8 \%$ indicates that it is an adjustment of the $\mathrm{R}$ squared that penalizes the addition of extraneous predictors to the model. The unstandardized constant statistic 2.819 units show that the model would predict if all of the four independent variables are Zero. The $\beta$ coefficient for Heuristic variables is 0.981 . This means that on average, if the Heuristic variables go up by 1 point, Investment performance of individual investors will improve by 0.981 units. The $\beta$ coefficient for Prospect variables is -0.360 . This means that on average, if the prospect variables go up by 1 point, Investment performance of individual investors will decrease by 0.360 units. Similarly, the $\beta$ coefficient for Market variables is -0.417 and the $\beta$ coefficient for herding variables is -0.121 .

Based on Table 10, the equation for the multiple regression line is,

$$
I P=2.819+0.918(H V)-0.360(P V)-0.417(M V)-0.121(H D V)+e
$$

\section{Hypotheses Testing}

According to the results of Pearson correlation analysis between Heuristic variables and Investment performance, the correlation of coefficient is 0.310 , which is significant at $1 \%$ $(p=0.000)$. As per results of multiple regression analysis between two variables, there is a positive relationship $(\beta=0.918, \mathrm{p}=0.000)$ at significant $1 \%$. Therefore, there is an evidence to reject $\mathrm{H} 0$ and it is concluded that heuristic variables positively impact on investment performance of CSE investors in the province.

The correlation of coefficient is -0.123 between Prospect variables and Investment performance at $5 \%$ significant. As per results of multiple regression analysis between two variables, there is a negative relationship $(\beta=-0.360, \mathrm{p}=0.002)$ at significant $1 \%$. Therefore, it is concluded that there is a negative impact of Prospect variables on investment performance of CSE investors in the province.

As per Pearson correlation analysis between Market variables and Investment performance, the correlation of coefficient is -0.070 , which is not significant at $5 \%$. However, multiple regression analysis between two variables shows that there is a 
negative relationship $(\beta=-0.417, \mathrm{p}=0.000)$ at significant $1 \%$. Therefore, there is evidence to reject $\mathrm{H} 0$ and it is concluded that there is a negative impact of Market variables on investment performance of CSE investors in the province.

Correlation between Herding variables and Investment performance is -0.029 , which is not significant at 5\%. As per results of multiple regression analysis between two variables, there is a negative relationship $(\beta=-0.121, \mathrm{p}=0.096)$ while it is not significant at $5 \%$. Therefore, there is no statistical evidence to reject $\mathrm{H} 0$ and it is concluded that there is no positive impact of herding variables on investment performance of CSE investors in Eastern province of Sri Lanka.

\section{Discussion}

\section{Heuristics Variables and Investment Performance}

Heuristics variables have positive impact on the investment performance, which implies that Representativeness, Overconfidence, Anchoring, Gamblers fallacy, and Availability are directly proportional to the investment result. Investment performance is affected by the predictive skill of investors and this ability cause to define a range for a share price or company's income based on the historical trends, resulting in under-reaction to unexpected changes. Trading of investors was influenced by recent experiences about price in the market, and whether they use the purchase price of stocks as a reference point while making trading decisions. Availability Investors make use of easily available information excessively. In the stock trading area, this bias manifests itself through the preference of investing in local companies which investors are familiar with or easily obtain information. This finding strongly supports the studies of Allen and Evans (2005), Gervais, Simon and Odean (2001) which suggest that people usually believe in their skills and knowledge to outperform the market.

\section{Prospect Variables and Investment Performance}

There is negative impact between prospect variables and investment performance. In terms of regret aversion which manifests itself by the fact that investors avoid selling decreasing shares; whereas, they are willing to sell increasing ones. The result shows that these behaviors affect negatively to investment performance. Regret aversion is common actions of investors. The reason is that when the stock price is going up, traders want to realize profit to show their ability. In contrast, when the price is going down, they do not want to be a loser so they keep the stocks and expect that its trend will reverse.

This explanation is consistent with the argument of Lehenkari \& Perttunen (2004), \& Shefrin \& Statman (1985). Another reason is that, in decreasing periods, the market liquidity is very low as buyers want to buy at floor price while sellers want to sell at ceiling price. Thus, selling losing stock is more difficult than winning ones. 
Regarding loss aversion after a gain, people are more confident about their ability, which leads to a hasty decision. Previous gain may make them become greedier and seek for more profits by investing more money. Thus, when unexpected things happen, the loss will be much higher than usual. In contrast, after a loss, people are certainly depressed. They become diffident when facing a decision.

They seek as much information as possible and analyze them carefully. They only invest when they are sure of success. In reality, there is no investment without risk, so without taking risk investors cannot look for high return. Although, investors should consider carefully before making decisions, too much carefulness may lead to slow actions, thus they may miss a good chance for investment and reduce opportunities to achieve high profits

\section{Market Variables and Investment Performance}

Market variables also have negative impact. The finding concurs with the finding of DeBondt and Thaler (1985) which reveals that changes in market information, fundamentals of the underlying stock and stock price can cause over/under-reaction to the price change and highly influence on decision-making behaviour of investors. Similarly, this finding slightly matches with findings of Luong and Ha (2011) where they find market variables highly impact on investment performance

\section{Herding Variables and Investment Performance}

Herding Variables also have a negative impact on investment performance. Stock market is lack of reliable information, so herding behaviour is understandable. When many people re-act the same, a wave is created and anyone who can catch that wave will earn profits. Individuals can dominate the price of some stocks. Thus, following these dominants may probably help investors to improve the investment, herding investors try to be as good as their peers, and non-herding traders seek to be better than competitors (Lutje, 2009). Therefore, in order to have higher returns, investors may have to consider the negative and positive impacts of herding carefully before making investment decisions.

\section{CONCLUSIONS AND IMPLICATION OF THE STUDY}

\section{Conclusion}

Objective one is to identify four behavioural factors that affect the investment performance of the Eastern province investors at CSE: Heuristic, Prospect, Market and Herding variables. Heuristic variables consist of five dimensions and anchoring factor is high level among those dimensions because investors rely on their skill, knowledge and previous experience regarding in the market and used to predict investment activities with the help of their own ability and experience. Prospect variables consist of three 
dimensions namely loss aversion, regret aversion and mental accounting which are moderate level. It is concluded that Eastern province investors mostly avoid loss and regret in investment on stocks. They prefer to stay in a safe or comfort zone. Out of six dimensions of Market variables, price changes factor and market information are high level. It clearly confirms that Eastern province investors carefully consider the price changes of stocks that they intend to invest. Based on the finding of customer preference in the market variables, they moderately analyze the companies' customer preference before they invest in the stocks. Herding variable is also a moderate level of investment performance because Eastern province investors follow others' decisions and react to others' decisions.

Objective two examines how behavioural factors impact on investment performance of CSE investors in Eastern province of Sri Lanka. It is concluded that around $23 \%$ of variation of the investment performance of Eastern province investors can be explained by encompassing all independent variables. Heuristic variables are found to have a positive significant impact on the investment performance than other variables. In contrast, Prospect, Market and Herding variables negatively impact on the investment performance of Eastern province investors at Colombo Stock Exchange. However, finding multiple regression about Herding variables is not significant. It reveals finding of herding variables cannot be generalized but it is only limited to the selected sample.

Gain on investment is decreased due to sample respondents are considered another investors' decision as there is a negative relationship between herding variables and investment performance. Investors are induced to follow others due to lack of information regarding the stock market which is reflected in more investors are not completed stock market related courses. According to findings of prospect variables, when the investors increase the level of Loss Aversion as well as Regret Aversion, return on investment decreases. In other words when they take more risk, they can earn more gain.

\section{Recommendations of the Study}

It is suggested to follow stock market related courses as investors are induced to follow others due to lack of information regarding the stock market. Overconfidence is a higher level in determining their investment performance whereas they are avoiding loss and regret. Therefore, individual investors at the CSE should be confident to utilize their skills and knowledge properly to enhance their outcome of investment.

Prospect Variables have a negative impact on investment performance. Moreover, it is identified that most respondents are Regret aversion on the decision making of the investors at the CSE. Even though investors have prior gain, they do not seek more risk than usual in the Eastern Province. Further, after prior loss, they are more risk averse. 
This phenomenon reveals that investors in Eastern Province are focusing on loss aversion. Therefore, it is recommended that investors should take risk through carefully studying market variables to earn better results. Further, they have to properly decide the portfolio of investment from different sectors.

Market variables also negatively influence on investment performance. Therefore, seminars and courses can be organized to improve knowledge of investors in Eastern province. It helps not only increase investment of prevailing investors but also attract new investors. Investors should understand companies' preference of customers. It will help them to predict company performance as well as investment performance.

\section{Contribution of the Study}

Heuristic and Prospect theories are applied in this study in addition to the market and herding variables in order to understand the behaviour pattern of CSE investors in Eastern province of Sri Lanka. It explores the investors' behaviour through theoretical perspectives. By achieving the research objective, this research provides investment behaviour of CSE investors in Eastern province of Sri Lanka. Further, the study explains how behavioural factors influence on investment performance of CSE investors in Eastern province of Sri Lanka.

\section{FURTHER LINE OF RESEARCH}

It is vital to conduct more research to confirm the findings of this research by covering investors island wide as well as comparing district wise. Another study could be conducted to understand how institutional investors as well as foreign investors behave at the Colombo Stock Exchange. Moreover, comparative study could be undertaken in Sri Lanka as well as other developed and developing countries in order to explore whether cultural values impact on investment performance. Finally, it is useful to conduct behavioural factors of investors in all kinds of securities such as debentures, unit trust, etc.

\section{REFERENCES}

Abu-Nassar, M., \& Rutherford B. A. (1996). External users of financial reports in less developed countries: The case of Jordon. The British Accounting Review, 28(1), 73-87.

Ackert, L. F., (2014). Chapter 2: Traditional and Behavioural Finance. Investor Behavior: The Psychology of Financial Planning and Investing. H. Kent Baker and Victor Ricciardi, editors, 25-41. Hoboken, NJ: John Wiley \& Sons, Inc., 2014. Retrieved from SSRN: http://ssrn.com/abstract=2394549 
Barber, B.M. and Odean, T. (2000). Trading is hazardous to your wealth: the common stock investment performance of individual investors. Journal of Finance, 55(2), 773 806.

Barberis, N., \& Huang, M. (2001). Mental Accounting, Loss Aversion, and Individual Stock Returns. The Journal of Finance, 56(4), 1247-1292.

Barberis, N., \& Thaler, R. (2003). A Survey of Behavioral Finance. Handbook of the economics of finance, 1B. Financial markets and asset pricing, 1053-1123.

Belsky, G., \& Gilovich. (1999). Why smart people make big money mistakes-and How to correct them: Lesson from the new science of behavioural economics Simon and Schuster, New York.

Bikhchandani, S. \& Sharma, S. (2001). Herd Behavior in Financial Markets, International Monetary Fund, 47(3), Retrieved from,

https://www.imf.org/External/Pubs/FT/staffp/2001/01/pdf/Bikhchan.pdf

Blume, M., \& Friend. (1978). The Changing Role of The Individual Investor.

Camerer, Colin F. and Dan Lovallo. (1999). Overconfidence and Excess Entry: An Experimental Approach. American Economic Review, 89(1), 306-18.

Central Bank of Sri Lanka. (2018). Financial Sector Performance and System Stability, Annual Report 2018, Colombo: Central Bank of Sri Lanka

Central Depository System. (2016). CDS participants, Colombo Stock Exchange.

Ceylontoday, (2016-01-24) Invest in East, Retrieved from http://ceylontoday.lk/22115997-news-detail-invest-in-east-2016.html

DeBondt, W.F.M., \& Thaler, R. (1995). Financial Decision-Making in Markets and Firms: A Behavioral Perspective. Handbooks in Operations Research and Management Science, 9(13), 385-410.

Fama, E. F. (1970). Efficient capital markets: A review of theory and empirical work. Journal of Finance, 25(2), 383-417

Fogel, O., \& Berry, T. (2006). The disposition effect and individual investor decisions: the roles of regret and counterfactual alternatives. Journal of Behavioral Finance, 7(2), $107-116$.

Glaser, M. \& Weber, M. (2007). Overconfidence and trading volume. The Geneva Risk and Insurance Review. 32(1), pp. 1-36 
Hettiarachchi, U. S., \& Rajeshwaran, N. (2016). The Impact of Dividend Policy on Stock Price: An Empirical Evidence from Hotels and Travels Companies Listed in Colombo Stock Exchange. International Conference in Accounting Researchers and Educators. Retrieved from: http://repository.kln.ac.lk/handle/123456789/16407.

Hirshleifer, D. (2001). Investor psychology and asset pricing. Journal of Finance 56, pp.1533-1597.

Huang, J.Y; Shieh, J.C.P. and Kao, Y. (2016). Starting points for a new researcher in behavioral finance. International Journal of Managerial Finance, 12(1) 92-103 Retrieved from http://dx.doi.org/10.1108/IJMF-05-2015-0111

Jayaraj, S. (2013). The Factor Model for Determining the Individual Investment behavior in India, IOSR Journal of Economics and Finance, 4(1)

Kahneman, D., \& Tversky, A. (1974). Judgment under Uncertainty: Heuristics and Biases. Science, 85 (4157), 1124-1131

Kahneman, D., \& Tversky, A. (1979). Prospect theory: an analysis of decision-making under risk. Econometrica, 47(2), 263-291.

Kengatharan, L. \& Kengatharan, N. (2014). The Influence of Behavioral Factors in Making Investment Decisions and Performance: Study on Investors of Colombo Stock Exchange, Sri Lanka. Asian Journal of Finance \& Accounting, 6(1), Retrieved from www.macrothink.org/ajfa.

Kim, K., \& Nofsinger, J. (2003). The Behaviour and Performance of Individual Investors in Japan.

Lai, M. (2001). Are Malaysian investors rational? Journal of Psychology and Financial Markets, 2(4), 210-215.

Lehenkari, M., \& Perttunen, J. (2004). Holding onto the losers: finish evidence. The Journal of Behavioral Finance, 5(2), 116-126.

Lin, A., \& Swanson, P. (2003). The Behavior and Performance of Foreign Investors in merging Equity Markets: Evidence from Taiwan. International Review of Finance.

Luong, L. P. \& Ha, D. T. T. (2011). Behavioral factors influencing individual investors' decision-making and performance A survey at the Ho Chi Minh Stock Exchange. Master thesis, Umea University, Sweden.

Lutje, T. (2009). To be good or to be better: asset managers' attitudes towards herding. Applied Financial Economics, 19(10), 825-839. 
Maditinos, D. I., Sevic, Z., and Theriou, N. G. (2007). Investors' behavior in the Athens Stock Exchange (ASE). Studies in Economics and Finance, 24(1), 32-50.

Menike, L.M.C.S (2006). The Effect of Macroeconomic Variables on Stock Prices in Emerging Sri Lankan Stock Market. Sabaragamuwa University Journal, 6(1), 50-67

Menike M. G. P. D. \& Prabath U. S. (2014). The Impact of Accounting Variables on Stock Price: Evidence from the Colombo Stock Exchange, Sri Lanka, International Journal of Business and Management; Vol. 9, No. 5, Published by Canadian Center of Science and Education

Nagy, R., A. \& Obenberger, R., W. (1994). Factors influencing individual investor behavior. Financial Analyst Journal, 50(4), 63-68.

Nunnally, J. C. (1978). Psychometric theory. New York: McGraw-Hill.

Oberlechner, T. and Osler, C., L. (2004). Overconfidence in currency markets.

Odean, T. (1998). Volume, volatility, price and profit when all trades are above average. Journal of Finance, 55(2), 773-806.

Odean, T. (1999). Do investors trade too much? American Economic Review, 89(5), 1279-1298.

Ritter, J. R. (2003). Behavioral Finance. Pacific-Basin Finance Journal, 11(4), 429-437.

Rockenbach, B. (2004). The behavioral relevance of mental accounting for the pricing of financial options. Journal of Economic Behavior and Organization, 53(4), 513-527.

Sekaran, U. (2007). Research Methods for Business: A Skill Building Approach. 4th edn., New Delhi: Wiley India (P.) Ltd.

Sultana, S. T. \& Pardhasaradhi, S. (2012). An Empirical Analysis of Factors Influencing Indian Individual Equity Investors' Decision Making and Behavior. European Journal of Business and Management. 4(18)

The survey system, (2018). Sample Size Calculator, Retrieved from http://www.surveysystem.com/sscalc.htm

Waweru, N., M., Munyoki, E., \& Uliana, E. (2008). The effects of behavioral factors in investment decision-making: a survey of institutional investors operating at the Nairobi Stock Exchange. International Journal of Business and Emerging Ma 